\title{
BACTERIAL BIOFILM FORMATION VERSUS MAMMALIAN CELL GROWTH ON TITANIUM-BASED MONO- AND BI-FUNCTIONAL COATINGS
}

\author{
Guruprakash Subbiahdoss $^{1}$, Bidhari Pidhatika ${ }^{2}$, Geraldine Coullerez $^{2}$, Mirren Charnley ${ }^{2}$, Roel Kuijer ${ }^{1}$,
} Henny C. van der Mei ${ }^{1, *}$, Marcus Textor ${ }^{2}$, and Henk J. Busscher ${ }^{1}$

\author{
${ }^{1}$ Department of Biomedical Engineering, University Medical Center Groningen, Groningen and University of \\ Groningen, P.O. Box 196, 9700 AD Groningen, The Netherlands \\ ${ }^{2}$ Laboratory for Surface science and Technology, Department of Materials, ETH Zurich, Switzerland
}

\begin{abstract}
Biomaterials-associated-infections (BAI) are serious complications in modern medicine. Although non-adhesive coatings, like polymer-brush coatings, have been shown to prevent bacterial adhesion, they do not support cell growth. Bi-functional coatings are supposed to prevent biofilm formation while supporting tissue integration. Here, bacterial and cellular responses to poly(ethylene glycol) (PEG) brush-coatings on titanium oxide presenting the integrin-active peptide RGD (arginine-glycine-aspartic acid) (bioactive "PEG-RGD") were compared to monofunctional PEG brush-coatings (biopassive "PEG") and bare titanium oxide $\left(\mathrm{TiO}_{2}\right)$ surfaces under flow. Staphylococcus epidermidis ATCC 35983 was deposited on the surfaces under a shear rate of $11 \mathrm{~s}^{-1}$ for $2 \mathrm{~h}$ followed by seeding of U2OS osteoblasts. Subsequently, both $S$. epidermidis and U2OS cells were grown simultaneously on the surfaces for $48 \mathrm{~h}$ under low shear $\left(0.14 \mathrm{~s}^{-1}\right)$. After 2 h, staphylococcal adhesion was reduced to $3.6 \pm 1.8 \times 10^{3}$ and $6.0 \pm 3.9 \times 10^{3} \mathrm{~cm}^{-2}$ on PEG and PEG-RGD coatings respectively, compared to $1.3 \pm 0.4 \times 10^{5} \mathrm{~cm}^{-2}$ for the $\mathrm{TiO}_{2}$ surface. When allowed to grow for $48 \mathrm{~h}$, biofilms formed on all surfaces. However, biofilms detached from the PEG and PEG-RGD coatings when exposed to an elevated shear $\left(5.6 \mathrm{~s}^{-1}\right)$. U2OS cells neither adhered nor spread on PEG brush-coatings, regardless of the presence of biofilm. In contrast, in the presence of biofilm, U2OS cells adhered and spread on PEG-RGD coatings with a significantly higher surface coverage than on bare $\mathrm{TiO}_{2}$. The detachment of biofilm and the high cell surface coverage revealed the potential significance of PEG-RGD coatings in the context of the "race for the surface" between bacteria and mammalian cells.
\end{abstract}

Keywords: Biomaterials-associated infections, polymer brush, polyethylene glycol brush coating, U2OS osteoblast, Staphylococcus epidermidis, biofilm, tissue integration, non-adhesive fouling.

*Address for correspondence:

Henny C. van der Mei

Department of Biomedical Engineering

University Medical Center Groningen and University of Groningen

P.O. Box 196, 9700 AD Groningen, The Netherlands

Telephone Number: 31-50-3633140

FAX Number: 31-50-3633159

E-mail: h.c.van.der.mei@med.umcg.nl

\section{Introduction}

Biomaterial-associated-infections (BAI) remain a major cause of failure of biomaterial implants. Biomaterial implants may become contaminated with microorganisms during implant surgery (peri-operative contamination) or during hospitalization (Gristina, 1987), causing the onset of BAI. Microorganisms involved in BAI are protected from antibiotics due to their biofilm mode of growth. Consequently, infected implants often have to be removed and a new implant can only be inserted once complete eradication of the infected surrounding tissue has been performed. Successful tissue integration depends on the outcome of the race for the surface between microorganisms and tissue cells (Gristina, 1987). If this race is won by tissue cells, then the biomaterial surface is covered by a cellular layer and is less vulnerable to biofilm formation. On the other hand, if the race is won by bacteria, the implant surface will become colonized by bacteria, and tissue cell functions are hampered by bacterial virulence factors (Gristina et al., 1988). Since microorganisms are frequently introduced on an implant surface during surgery, microorganisms often start the race for the surface before tissue integration can even occur (Gristina et al., 1988).

Biofilm formation occurs on all currently used biomaterials. Microbial adhesion to biomaterials is determined by the physicochemical properties of the implant surface (Hermansson, 1999). Thus, modification of an implant surface may be able to prevent bacterial adhesion and biofilm formation. Several surface modification methods (Morra, 2000; Vasilev et al., 2009, Schuler et al., 2006), such as hydrophilic polymer brushtype surfaces (in particular poly(ethylene glycol) PEG), have been developed to prevent bacterial adhesion and biofilm formation (Maddikeri et al., 2008). However, such non-adhesive polymer coatings also resist adhesion, spreading and growth of mammalian cells (Schuler et al., 2006; VandeVondele et al., 2003), which are required for successful tissue integration.

In order to prepare bi-functional coatings which prevent microbial adhesion while supporting tissue cell growth, the biologically inert poly(L-lysine)-graftpoly(ethylene glycol) (PLL-g-PEG) copolymer was modified with the arginine-glycine-aspartic acid (RGD) peptide sequence (VandeVondele et al., 2003). The RGD peptide is known as one of the major recognition sites of integrin receptors through which mammalian cells connect to their extracellular matrix molecules (Lebaron and Athanasiou, 2000). In earlier studies, reduced bacterial adhesion on bi-functional PLL-g-PEG/PEG-RGD- 
modified surfaces has been demonstrated separately from their ability to support mammalian cell growth (Maddikeri et al., 2008; Shi et al., 2008). However, a simultaneous study on bacterial biofilm formation and mammalian cell growth, i.e., an actual "race for the surface", has not been performed due to lack of proper methodology. Recently, an in vitro experimental methodology to investigate bacterial biofilm formation and mammalian cell growth in a single experiment was developed (Subbiahdoss et al., 2009). The outcome of the competition between Staphylococcus epidermidis and U2OS cells appeared to be dependent on the number of bacteria present prior to cell seeding and the absence or presence of fluid flow. Mammalian cells lost the competition in the absence of flow due to the accumulation of bacterial toxins, but were able to grow under flow due to the continuous supply of fresh medium to and removal of endotoxins from the interface. A further study of the race for the surface on different biomaterials demonstrated that mammalian cell interactions with biomaterials were hampered by bacterial biofilm formation on all commonly used biomaterial surfaces (Subbiahdoss et al., 2010).

This study aimed at evaluating titanium oxide surfaces modified with biopassive PLL-g-PEG and bioactive PLLg-PEG/PEG-RGD with respect to biofilm formation and simultaneous mammalian cell adhesion, spreading and growth. In particular the hypothesis that the bi-functional, bioactive surface may favour mammalian cell interaction over biofilm formation, is tested.

\section{Materials and Methods}

\section{$\mathrm{TiO}_{2}$-coated glass slides}

Microscope glass slides $(76 \times 26 \mathrm{~mm})$ were purchased from Menzel $\mathrm{GmBH}+\mathrm{Co} \mathrm{KG}$, Braunschweig, Germany. The glass slides were sputter-coated with a $21 \mathrm{~nm}$ thick $\mathrm{TiO}_{2}$ layer (reactive magnetron sputtering, Paul Scherrer Institute, Villigen, Switzerland).

\section{PLL-g-PEG and PLL-g-PEG/PEG-RGD}

PLL-g-PEG and PLL-g-PEG/PEG-RGD were purchased from Surface Solutions AG (Dübendorf, Switzerland). PLL-g-PEG is a copolymer with a polycationic PLL backbone onto which non-functionalized (methoxyterminated) PEG chains are grafted. Grafting ratio, expressed as $\mathrm{g}$, represents the ratio between number of lysine units and number of grafted PEG chains ( $g=$ Lys/ PEG). PLL-g-PEG/PEG-RGD describes a copolymer with a PLL backbone onto which two different types of PEG chains are grafted, i.e. non-functionalized PEG and RGDfunctionalized PEG (VandeVondele et al., 2003).

The molecular weights of PLL, non-functionalized PEG and RGD-functionalized PEG, are $20 \mathrm{kDa}, 2 \mathrm{kDa}$, and $3.4 \mathrm{kDa}$, respectively. The grafting ratio $(\mathrm{g})$ of both copolymers PLL-g-PEG and PLL-g-PEG/PEG-RGD is 3.5. For the latter, $8 \%$ of all PEG chain carry the terminal, covalently linked peptide GCRGYGRGDSPG.

Surface preparation and polymer adsorption The copolymers were dissolved at a $0.25 \mathrm{mg} / \mathrm{mL}$ concentration in HEPES II buffer (10 mM HEPES and $150 \mathrm{mM} \mathrm{NaCl}$, adjusted to $\mathrm{pH} 7.4$ by addition of $\mathrm{NaOH}$ ). The polymer solutions were filter-sterilized $(0.22 \mu \mathrm{m}$ filter), aliquoted and stored at $-20^{\circ} \mathrm{C}$ until use. Prior to surface modification, $\mathrm{TiO}_{2}$-coated glass slides were ultrasonicated for $10 \mathrm{~min}$ in a cleansing solution $(300 \mathrm{mM}$ hydrochloric acid and 1\% detergent, Cobas Integra ${ }^{\circledR}$, Roche Diagnostic, Indianapolis, IN, USA), rinsed with ultra pure water, followed by 10 min ultrasonication in 2-propanol to remove the adventitious macroscopic contamination and blow-drying under a stream of nitrogen. Subsequently, the $\mathrm{TiO}_{2}$-coated glass slides were cleaned by means of oxygen plasma treatment for $2 \mathrm{~min}$ (Plasma cleaner/sterilizer PDC32G, Harrick Scientific Products Inc., Pleasantville, NY, USA). Copolymer solutions were subsequently placed onto the pre-cleaned substrates completely covering their surfaces. Copolymer adsorption was allowed to proceed for $1 \mathrm{~h}$ to provide a complete monolayer on the surface, followed by extensive washing with HEPES II buffer, ultrapure water, and finally blow-drying under a stream of nitrogen. Data on conformation of the used copolymers adlayers and interaction with proteins have been described elsewhere (Pasche et al., 2003).

The copolymer-modified substrates were placed in a clean sample holder and stored at $4^{\circ} \mathrm{C}$ until use. The surfaces are denoted as " $\mathrm{TiO}_{2}$ " for bare titanium oxide surface, "PEG" for PLL-g-PEG-modified and "PEGRGD” for PLL-g-PEG/PEG-RGD-modified surface. The surfaces were sterilized using $70 \%$ ethanol and washed with sterile ultrapure water before use.

\section{Bacterial growth conditions and harvesting}

S. epidermidis ATCC 35983, originally isolated from human blood of a patient with an infected intravascular catheter, and known to produce polysaccharide integrin adhesin (Dhanawade et al., 2010), was used throughout this study. First, the strain was streaked on a blood agar plate from a frozen stock and grown overnight at $37^{\circ} \mathrm{C}$. The plate was then kept at $4^{\circ} \mathrm{C}$. For each experiment, a colony was inoculated in $10 \mathrm{~mL}$ of tryptone soya broth (TSB; OXOID, Basingstoke, England) and cultured for $24 \mathrm{~h}$. This culture was used to inoculate a second culture, which was grown for $17 \mathrm{~h}$ prior to harvesting. Bacteria were harvested by centrifugation at $5000 \mathrm{~g}$ for $5 \mathrm{~min}$ at $10^{\circ} \mathrm{C}$ and washed twice with sterile ultrapure water. Subsequently, the harvested bacteria were ultrasonicated on ice $(3 \times 10 \mathrm{~s})$ in sterile phosphate buffered saline (PBS) (10 $\mathrm{mM}$ potassium phosphate, $0.15 \mathrm{M} \mathrm{NaCl}, \mathrm{pH} 7.0$ ) in order to break bacterial aggregates. This suspension was further diluted in sterile PBS to a concentration of $3 \times 10^{6}$ bacteria/mL.

\section{Mammalian cell culturing and harvesting}

U2OS osteosarcoma cells were cultured in Dulbecco's modified Eagles Medium (DMEM)-low glucose supplemented with $10 \%$ foetal bovine serum (FBS) and $0.2 \mathrm{mM}$ of ascorbic acid-2-phosphate (AA2P) without antibiotics, denoted "DMEM+FBS". Osteoblasts were maintained at $37^{\circ} \mathrm{C}$ in a humidified $5 \% \mathrm{CO}_{2}$ atmosphere, and passaged at 70-90\% confluency using trypsin/ ethylenediamine-tetraacetic acid (EDTA). 


\section{Bacteria and tissue cell competitive adhesion assays} Competitive adhesion assays were performed on the bottom plate of a parallel plate flow chamber $(175 \times 17 \times 0.75$ $\mathrm{mm}^{3}$ ) prepared from the biomaterial surfaces with or without polymer coatings under investigation, as described in detail elsewhere (Subbiahdoss et al., 2009). Importantly, the flow chamber was equipped with heating elements and kept at $37^{\circ} \mathrm{C}$ throughout the experiments. Bacterial and U2OS cell deposition were observed with a CCD camera (Basler AG, Ahrensburg, Germany) mounted on a phasecontrast Leica DM2000 microscope (Leica Microsystems Ltd, Wetzlar, Germany) with a x30 objective for bacteria and $\mathrm{x} 10$ objective for mammalian cells.

Prior to each experiment, all tubes and the flow chamber were filled with sterile PBS, to ensure all air bubbles were removed from the system. Prior to the addition of bacterial suspension, sterile PBS was allowed to flow through the system at a shear rate of $11 \mathrm{~s}^{-1}$. Subsequently, the bacterial suspension in PBS was perfused through the chamber at the same shear rate for $2 \mathrm{~h}$. Images were obtained continuously and the number of bacteria per unit area were analyzed in real-time by using proprietary software based on the Matlab Image processing Toolkit (The MathWorks, Natick, MA, USA). The flow with shear rate of $11 \mathrm{~s}^{-1}$ was then re-initiated to deliver sterile PBS to remove unattached bacteria from the tubes and flow chamber, after which a U2OS cell suspension $\left(6 \times 10^{5}\right.$ cells $\left./ \mathrm{mL}\right)$ in modified culture medium, consisting of $98 \%$ DMEM+FBS and $2 \%$ TSB which is suitable for the simultaneous growth of U2OS cells and S. epidermidis (Subbiahdoss et al., 2009), was allowed to enter the flow chamber. Once the entire volume of buffer inside the chamber was replaced by the cell suspension, the flow was stopped for $1.5 \mathrm{~h}$ in order to allow tissue cells to adhere and spread on the substratum. Subsequently, phase contrast images (nine images on different locations, $900 \times 700 \mu \mathrm{m}^{2}$ each) were taken to determine the number of adhering cells per unit area and the area per spread cell using Scion image analysis software (Scion, Frederick, MD, USA). Finally, modified culture medium supplemented with 2\% HEPES was perfused through the system at a low shear rate of $0.14 \mathrm{~s}^{-1}$ for $48 \mathrm{~h}$, and phase-contrast images were collected continuously.
After $48 \mathrm{~h}$ of growth, the shear stress was increased to 5.6 $\mathrm{s}^{-1}$ for $30 \mathrm{~min}$, i.e. a value that is lower than the one used during initial bacterial adhesion $\left(11 \mathrm{~s}^{-1}\right)$. Subsequently, U2OS cells and bacterial biofilm growth were monitored continuously. Control experiments with only U2OS cells (in the absence of $S$. epidermidis) were performed using the above procedure.

Finally, the adhering U2OS cells were stained with TRITC-Phalloidin for quantitative analysis. Briefly, the substrate surfaces with adhering bacteria and tissue cells were fixed with $30 \mathrm{~mL}$ of $3.7 \%$ formaldehyde in cytoskeleton stabilization buffer (CS; 0.1M PIPES, $1 \mathrm{mM}$ EGTA, 4\% (w/v) polyethylene glycol 8000, pH 6.9). After $5 \mathrm{~min}$, the fixation solution was replaced with $30 \mathrm{~mL}$ of fresh CS for another $5 \mathrm{~min}$. Subsequently, U2OS cells were incubated in $0.5 \%$ Triton X-100 for $3 \mathrm{~min}$, rinsed with PBS, stained for $30 \mathrm{~min}$ with $5 \mathrm{~mL}$ PBS containing $49 \mu \mathrm{L}$ DAPI and $2 \mu \mathrm{g} / \mathrm{mL}$ of TRITC-Phalloidin, washed four times in PBS and examined with confocal laser scanning microscopy (CLSM, Leica DMRXE with confocal TCS SP2 unit equipped with a water immersion lens). Images (nine images on different locations, $900 \times 700 \mu \mathrm{m}^{2}$ each) were taken and the number of adhering cells per unit area and the average area per spread cell were determined.

\section{Statistical analysis}

Experiments on different surfaces were performed in triplicate. Data are represented as a mean with standard deviation. For statistical analysis ANOVA was performed followed by a Tukey's HSD post-hoc test and a $P$-value $<$ 0.05 was considered to be significant.

\section{Results}

\section{Bacterial adhesion}

Initial adhesion of $S$. epidermidis after $2 \mathrm{~h}$ of flow at a shear rate of $11 \mathrm{~s}^{-1}$ was significantly reduced to $3.6 \pm 1.8 \times$ $10^{3} \mathrm{~cm}^{-2}$ and $6.0 \pm 3.9 \times 10^{3} \mathrm{~cm}^{-2}$ on both PEG and PEGRGD coatings respectively, compared to $1.3 \pm 0.4 \times 10^{5}$ $\mathrm{cm}^{-2}$ on the bare $\mathrm{TiO}_{2}$ surface (Fig. 1). This demonstrates that in the presence of RGD-peptide sequences, the non-

Table 1: Number of cells, area of spread cells and surface coverage of U2OS cells on $\mathrm{TiO}_{2}, \mathrm{PEG}$ and PEG-RGD surfaces after initial seeding at $1.5 \mathrm{~h}$ and after $48 \mathrm{~h}$ of growth at a shear rate of $0.14 \mathrm{~s}^{-1}$ and subsequent application of an elevated shear rate $\left(5.6 \mathrm{~s}^{-1}\right)$ for $30 \mathrm{~min}$, in the absence and presence of adhering S. epidermidis. \pm indicates the standard deviation over three independently prepared and measured samples.

\begin{tabular}{|c|c|c|c|c|c|c|c|c|c|c|c|c|}
\hline \multirow{3}{*}{ Surfaces } & \multicolumn{6}{|c|}{ Absence of S. epidermidis } & \multicolumn{6}{|c|}{ Presence of S. epidermidis } \\
\hline & \multicolumn{2}{|c|}{$\begin{array}{l}\text { U2OS cell number } \\
\qquad 10^{3} \mathrm{~cm}^{-2}\end{array}$} & \multicolumn{2}{|c|}{$\begin{array}{c}\text { Area/cell } \\
\mu^{2}\end{array}$} & \multicolumn{2}{|c|}{$\begin{array}{c}\text { Surface coverage by } \\
\text { U2OS cells } \\
\%\end{array}$} & \multicolumn{2}{|c|}{$\begin{array}{l}\text { U2OS cell number } \\
\qquad 10^{3} \mathrm{~cm}^{-2}\end{array}$} & \multicolumn{2}{|c|}{$\begin{array}{c}\text { Area/cell } \\
\boldsymbol{\mu m}^{2}\end{array}$} & \multicolumn{2}{|c|}{$\begin{array}{c}\text { Surface coverage by } \\
\text { U2OS cells } \\
\%\end{array}$} \\
\hline & $1.5 \mathrm{~h}$ & $48 \mathrm{~h}$ & $1.5 \mathrm{~h}$ & $48 \mathrm{~h}$ & $1.5 \mathrm{~h}$ & $48 \mathrm{~h}$ & $1.5 \mathrm{~h}$ & $48 \mathrm{~h}$ & $1.5 \mathrm{~h}$ & $48 \mathrm{~h}$ & $1.5 \mathrm{~h}$ & $48 \mathrm{~h}$ \\
\hline $\mathrm{TiO}_{2}$ & $51 \pm 4$ & $59 \pm 9$ & $550 \pm 48$ & $1020 \pm 114$ & $27 \pm 2$ & $63 \pm 10$ & $45 \pm 3$ & $39 \pm 6$ & $620 \pm 55$ & $940 \pm 210$ & $27 \pm 2$ & $38 \pm 6$ \\
\hline PEG & $43 \pm 3$ & $*$ & $460 \pm 60$ & $*$ & $19 \pm 1$ & $*$ & $42 \pm 4$ & $*$ & $480 \pm 40$ & * & $19 \pm 2$ & $*$ \\
\hline $\begin{array}{c}\text { PEG - } \\
\text { RGD }\end{array}$ & $43 \pm 4$ & $56 \pm 9$ & $875 \pm 50$ & $1180 \pm 82$ & $36 \pm 4$ & $69 \pm 11$ & $43 \pm 3$ & $50 \pm 9$ & $1070 \pm 35$ & $1024 \pm 96$ & $44 \pm 4$ & $54 \pm 10$ \\
\hline
\end{tabular}

* no U2OS cells were detected on the surface. 


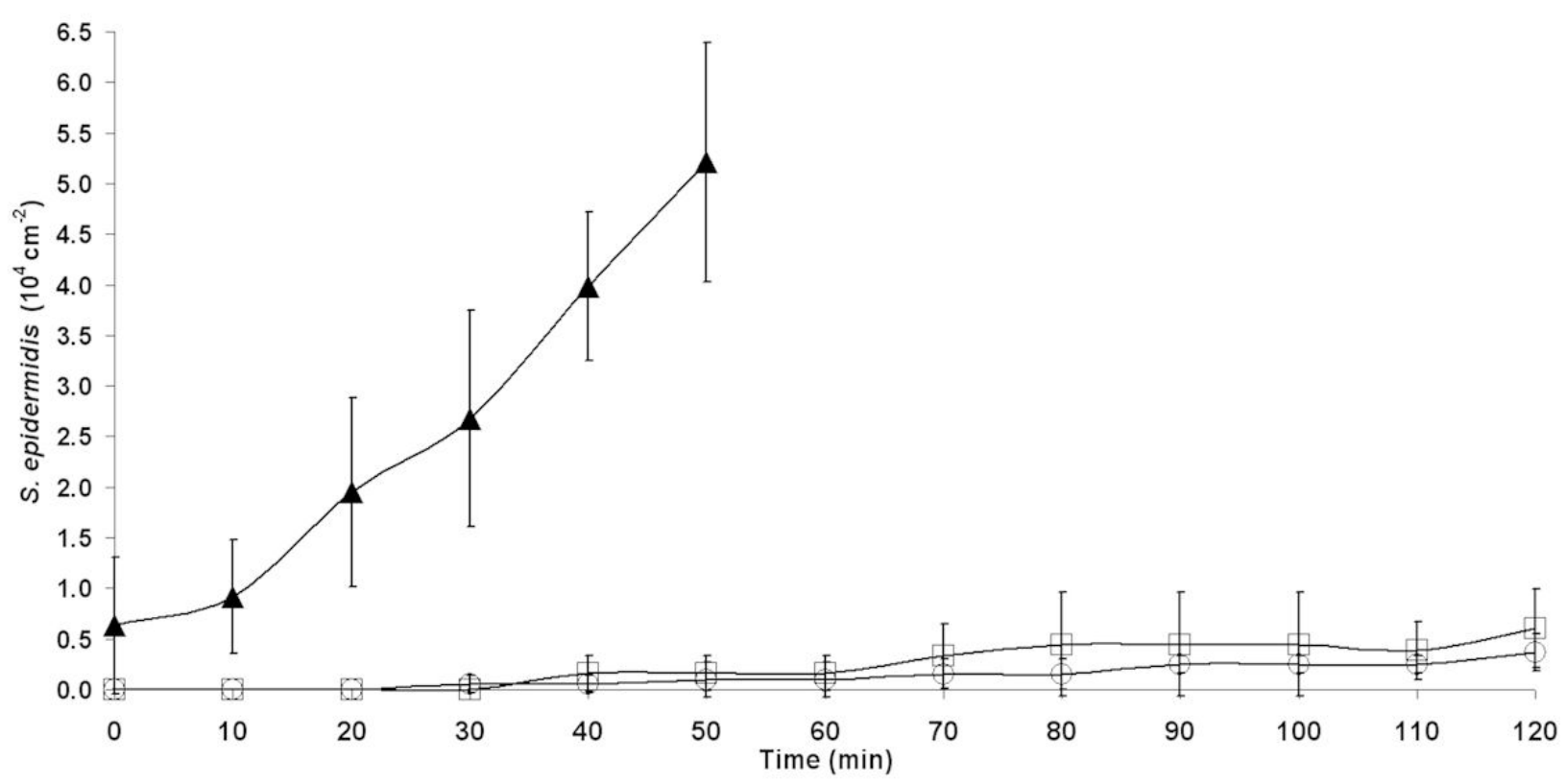

Fig. 1. The number of adhering S. epidermidis ATCC 35983 as a function of time in a parallel plate flow chamber (shear rate $11 \mathrm{~s}^{-1}$ ) on mono-functional PEG coating $(\bigcirc)$ and a bi-functional PEG-RGD coating $(\square)$ as well as on a bare $\mathrm{TiO}_{2}$ surface $(\boldsymbol{\Delta})$. Error bars represent the standard deviation over three replicates with separately cultured bacteria.

adhesive functionality of the PEG brush surface is still maintained.

\section{U2OS cell adhesion and spreading in the absence and presence of adhering $S$. epidermidis}

Immediately after seeding, U2OS cell adhesion and spreading was observed in the absence and presence of adhering $S$. epidermidis on $\mathrm{TiO}_{2}$ surfaces and PEG-RGD coatings, but not on the PEG coatings. At $1.5 \mathrm{~h}$, there was no significant difference in the number of adhering U2OS cells on the different surfaces (Table 1), but cell spreading was greater on PEG-RGD coatings, as compared to PEG coatings and $\mathrm{TiO}_{2}$ surfaces $(p<0.01)$, irrespective of absence or presence of $S$. epidermidis bacteria (Table 1).

After $48 \mathrm{~h}$, the adhering $S$. epidermidis had grown into a biofilm on all surfaces, but simultaneously U2OS cell adhesion and spreading was observed on $\mathrm{TiO}_{2}$ surfaces and PEG-RGD coatings (Fig. 2). On PEG coatings, U2OS cells that were loosely adhered retained a rounded morphology up to $48 \mathrm{~h}$ (Fig. 2e). Upon application of an elevated shear rate $\left(5.6 \mathrm{~s}^{-1}\right)$, biofilms detached from PEG and PEG-RGD coatings and partially from $\mathrm{TiO}_{2}$ surfaces, whereas U2OS cell detachment only occurred from the PEG coating (Fig. 2 g, h, and i).

After $48 \mathrm{~h}$ of growth and subsequent application of a higher shear, adhering U2OS cells were immunocytostained for CLSM analysis (Fig. 3) to derive the number and spread area of adhering U2OS cells in the absence and presence of staphylococci. In Fig. 4 it can be seen that on a percentage basis, the number of adhering U2OS cells was significantly reduced on $\mathrm{TiO}_{2}$ surfaces in the presence of S. epidermidis as compared to the control, i.e. in the absence of adhering bacteria $(p<0.05)$. In the presence of $S$. epidermidis, the percentage adhering U2OS cells decreased on $\mathrm{TiO}_{2}$ surfaces in contrast to that on bifunctional PEG-RGD coatings (Fig. 4) that showed an increase. U2OS cells showed no significant difference in spreading on PEG-RGD coating as compared to a $\mathrm{TiO}_{2}$ surface in the presence or absence of adhering $S$. epidermidis (Fig. 5 and Table 1).

\section{Surface coverage of U2OS cells in the absence and presence of adhering $S$. epidermidis}

Immediately after seeding at $1.5 \mathrm{~h}$, a significant increase in the surface coverage of U2OS cells was observed on PEG-RGD coatings compared to $\mathrm{TiO}_{2}$ surfaces and PEG coatings, irrespective of the absence or presence of adhering $S$. epidermidis (Table 1).

After $48 \mathrm{~h}$ of growth at low shear and subsequent application of an elevated shear for $30 \mathrm{~min}, \mathrm{TiO}_{2}$ surface showed a significant decrease in surface coverage in the presence of adhering staphylococci compared to the control, i.e., the absence of adhering staphylococci. On PEG coatings, no adhering U2OS cells were detected on the surface (Fig. 3 b, e). Conversely PEG-RGD coatings in the presence of adhering staphylococci showed no significant difference in surface coverage of U2OS cells compared to cells cultured in the absence of $S$. epidermidis.

\section{Discussion}

This paper is the first to experimentally demonstrate the advantage of bi-functional versus mono-functional coatings in the prevention of infection on implant surfaces by conducting the race for the surface between bacteria and mammalian cells, as eventually determining the fate of a biomaterial implant. Bi-functional coatings clearly remained non-adhesive to $S$. epidermidis, but at the same time supported mammalian cell adhesion and spreading to a greater extent than mono-functional coatings and a control surface, in this case a bare $\mathrm{TiO}_{2}$ surface. Titanium 
$\mathrm{TiO}_{2}$

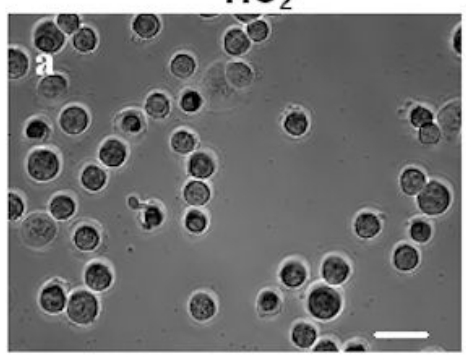

$1.5 \mathrm{~h}$
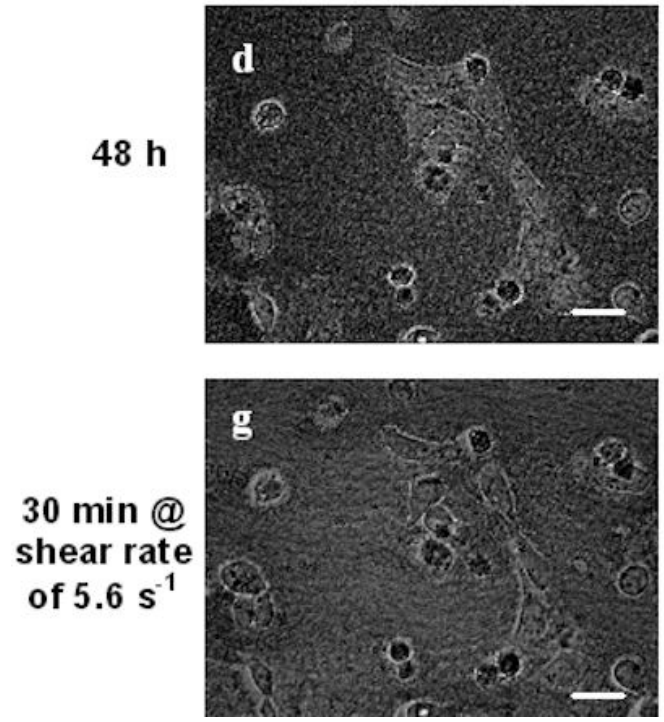

PEG
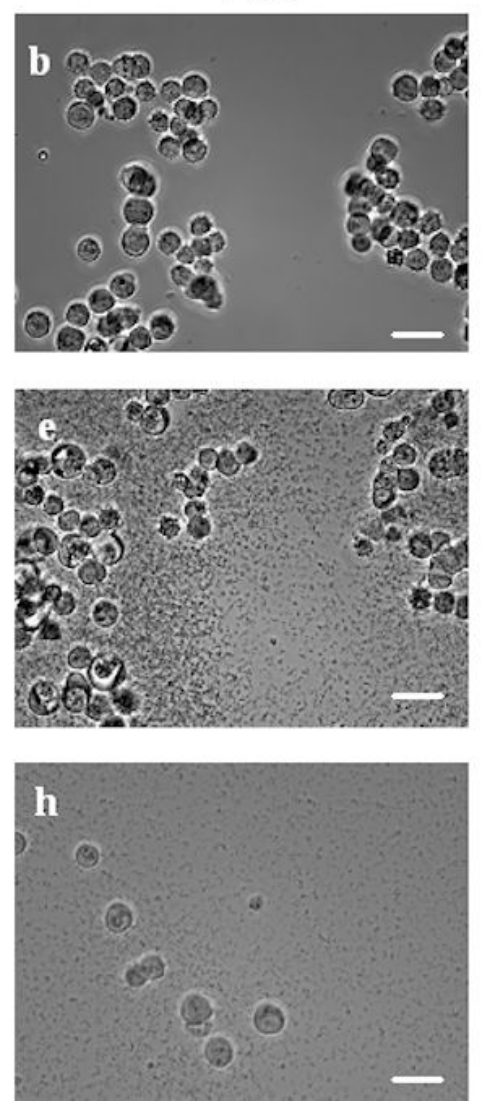

PEG - RGD
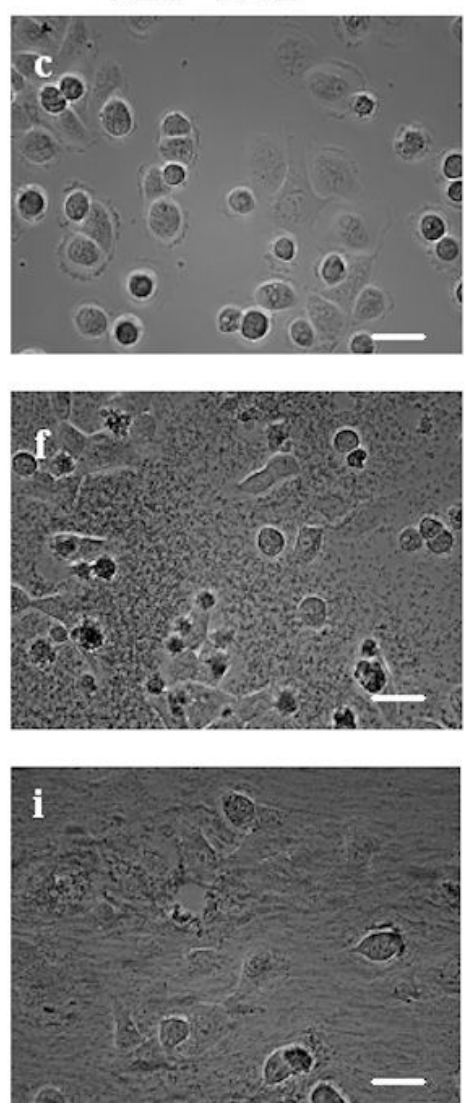

Fig. 2. Phase-contrast images of U2OS cell adhesion and spreading after seeding at $1.5 \mathrm{~h}$, after $48 \mathrm{~h}$ of growth at low shear $\left(0.14 \mathrm{~s}^{-1}\right)$ in the presence of adhering $S$. epidermidis as well as after an elevated shear $\left(5.6 \mathrm{~s}^{-1}\right)$ for $30 \mathrm{~min}$ at the end of the experiment, on PEG and PEG-RGD coatings, and on $\mathrm{TiO}_{2}$ control surfaces. At $1.5 \mathrm{~h}$, well spread U2OS cells were observed on PEG-RGD (c) compared to PEG coating (b) and $\mathrm{TiO}_{2}$ control surfaces (a), for which cell spreading was less. At $48 \mathrm{~h}$, biofilm formation and U2OS cell spreading were observed on $\mathrm{TiO}_{2}$ control surface (d) and PEG-RGD coating (f), whereas only biofilm formation and no cell spreading were seen on PEG coating (e). Upon application of an elevated shear, detachment of biofilm and U2OS cells was observed on PEG coatings (h), while only biofilm detachment occurred on PEG-RGD coating (i) and $\mathrm{TiO}_{2}$ surface (g). All images were taken at the same magnification. The bar denotes $10 \mu \mathrm{m}$.

is widely used in dental and orthopaedic implants, heart valves and vascular stents (Brunette et al., 2001). Titanium devices implanted in the body are covered with a layer of oxide, responsible for the favourable biocompatibility of titanium implants. Tissue cells reactions on $\mathrm{TiO}_{2}$ and pure titanium are very similar (Textor et al., 2001).

In our in vitro model, bacteria were allowed to adhere for $2 \mathrm{~h}$ prior to cell adhesion and spreading, which is considered to mimic the clinical situation where implants become contaminated prior to implantation. The number of bacteria adhering on PEG and PEG-RGD was $10^{3} \mathrm{~cm}^{-2}$ and $10^{5} \mathrm{~cm}^{-2}$ for $\mathrm{TiO}_{2}$, representing a reduction in initial bacterial load on polymer brush coatings of two log-units. Note that in this study we deliberately chose to fix the time for bacterial adhesion, and not to contaminate all surfaces with the same number of organisms. This choice allows comparing coatings and surfaces for their performance during a fixed surgical period. In the past, it has been documented that during a surgical procedure of $1 \mathrm{~h}$, the total number of bacteria carrying particles falling on the wound is about $270 \mathrm{~cm}^{-2}$ (Fitzgerald et al., 1979). The bacterial counts are generally higher during periods of activity and when more people are present in the operation theatre. More recent, through the use of modern, better-ventilated operation theatres (20 changes of air/h) and impermeable patient and personnel clothing, perioperative bacterial contamination may well be less (Verkkala et al., 1998). However, many surgical procedures in which implants are introduced in the body last much longer than $1 \mathrm{~h}$. Therefore, the bacterial adhesion densities chosen in our experiments represent a moderate to worst case scenario.

Significant reduction of bacterial adhesion on PEG and PEG-RGD-coated surfaces compared to that on bare $\mathrm{TiO}_{2}$ surface was previously reported (Maddikeri et al., 2008). In earlier studies (Harris et al., 2004; Wagner and Bryers, 2004), it was reported that the presence of a peptide covalently attached to PEG reduced bacterial adhesion similar to PEG coatings. In agreement with previous studies our results show that $S$. epidermidis showed no significant difference in adhesion on PEG coatings compared to PEGRGD coatings indicating that the $S$. epidermidis ATCC 35983 bacteria do not recognize the RGD, unlike mammalian cells recognize RGD via integrin receptors.

Cell adhesion to a biomaterial surface is a prerequisite for successful tissue integration. Mammalian cells bind to 


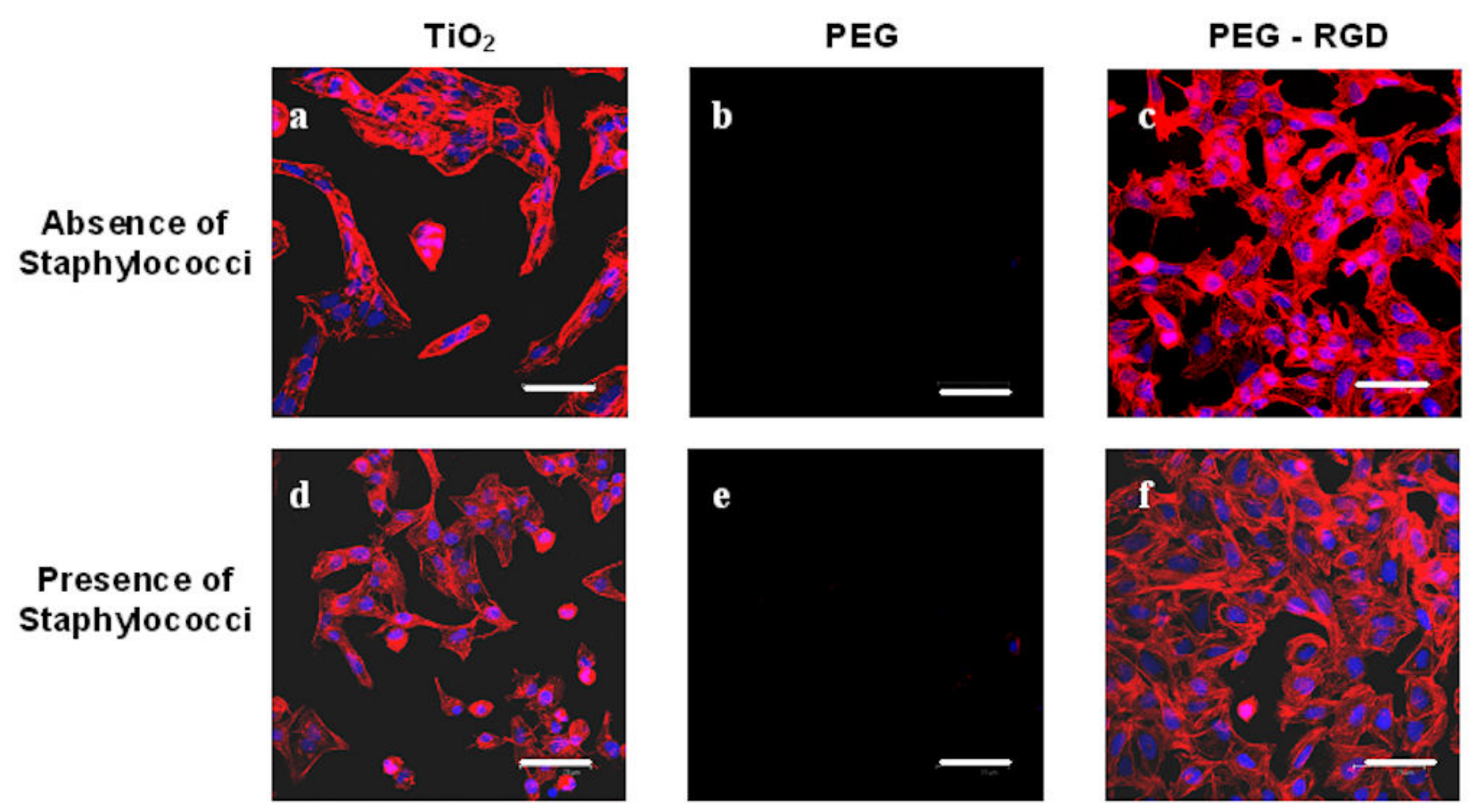

Fig. 3. CLSM images of U2OS cells after $48 \mathrm{~h}$ of growth at low shear $\left(0.14 \mathrm{~s}^{-1}\right)$ and subsequent application of an elevated shear $\left(5.6 \mathrm{~s}^{-1}\right)$ for $30 \mathrm{~min}$ on $\mathrm{TiO}_{2}$ surfaces, PEG and PEG-RGD coatings in the absence (a-c) and presence (d-f) of adhering S. epidermidis. U2OS cells were stained with $5 \mathrm{~mL}$ PBS containing $49 \mu \mathrm{L}$ DAPI and $2 \mu \mathrm{g} / \mathrm{mL}^{-1}$ of TRITC-phalloidin. All images were taken at the same magnification. The bar denotes $75 \mu \mathrm{m}$.

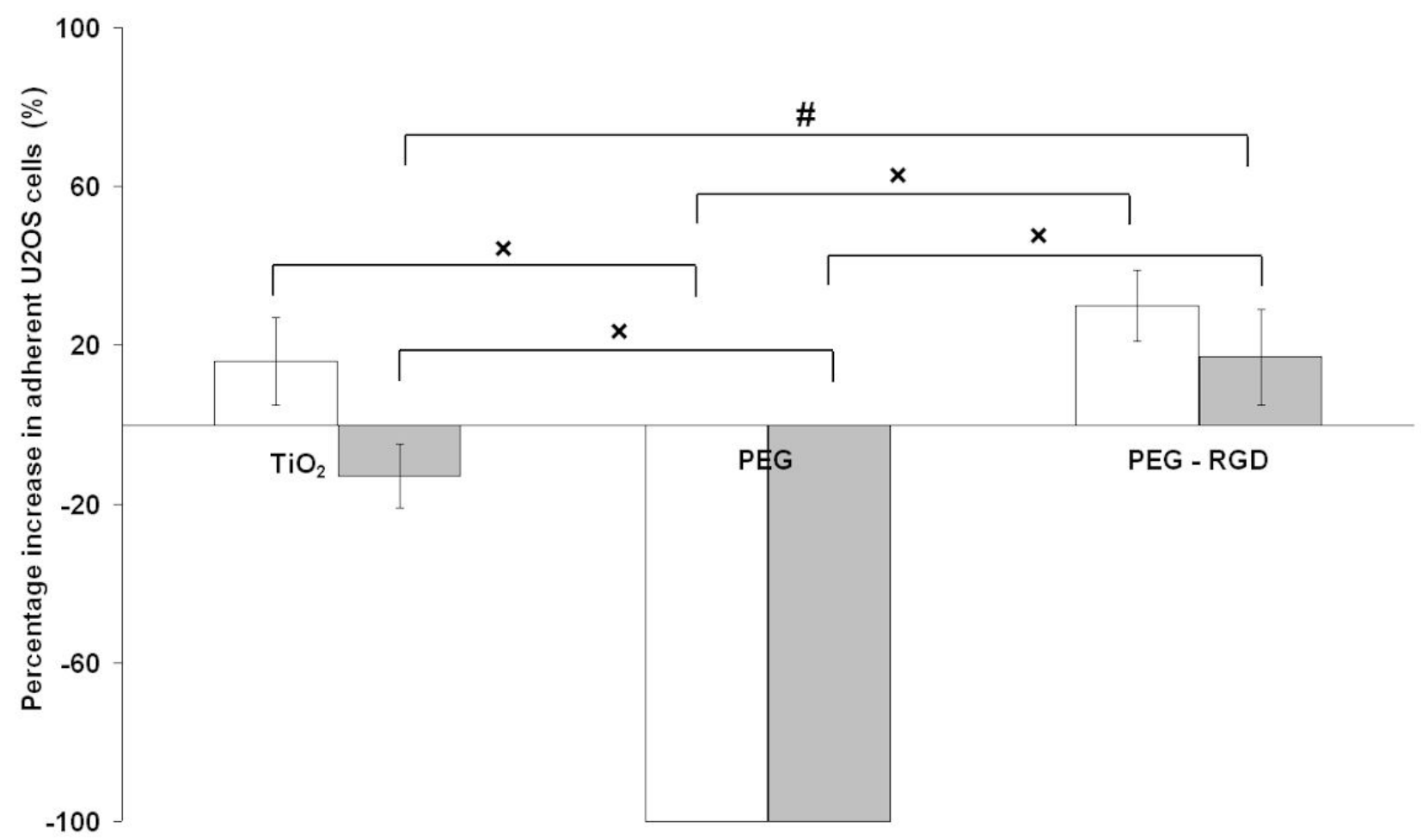

Fig. 4. The percentage increase in the number of adhering U2OS cells after $48 \mathrm{~h}$ of growth at low shear $(0.14$ $\left.\mathrm{s}^{-1}\right)$ and subsequent application of an elevated shear $\left(5.6 \mathrm{~s}^{-1}\right)$ for $30 \mathrm{~min}$ with respect to their initial number immediately after seeding at $1.5 \mathrm{~h}$ on $\mathrm{TiO}_{2}$ surfaces and PEG and PEG-RGD coatings in the absence ( $\square$ ) and presence ( $\square$ ) of adhering S. epidermidis ATCC 35983. Error bars represent the standard deviations over three replicates, with separately cultured bacteria and tissue cells.

${ }^{\times}$denotes significance at $p<0.01,{ }^{*}$ denotes significance at $p<0.05$. 


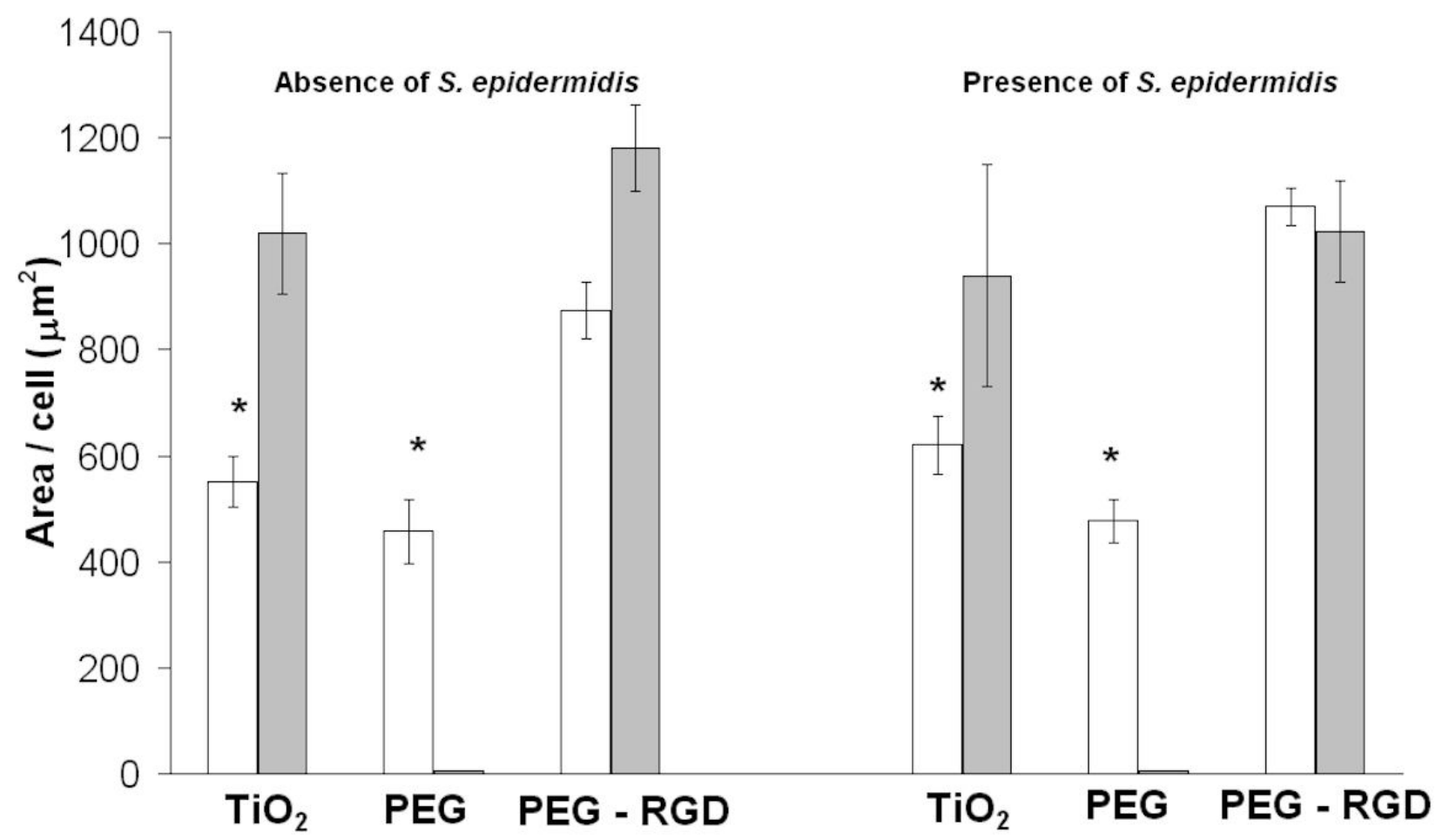

Fig. 5. The average area per adhering U2OS cell immediately after seeding at $1.5 \mathrm{~h}(\square)$ and after $48 \mathrm{~h}$ of growth at low shear $\left(0.14 \mathrm{~s}^{-1}\right)$ and subsequent application of an elevated shear $\left(5.6 \mathrm{~s}^{-1}\right)$ for $30 \mathrm{~min}(\square)$ on $\mathrm{TiO}_{2}$ surfaces, PEG and PEG-RGD coatings in the absence and presence of adhering S. epidermidis ATCC 35983. Error bars represent the standard deviations over three replicates, with separately cultured bacteria and tissue cells.

* denotes significance at differences at $p<0.01$ compared with PEG-RGD.

the biomaterial surface through adsorbed proteins and one of the main binding sites in these proteins is the RGD peptide sequence (Hersel et al., 2003). On PEG coatings, hardly any protein adsorbed resulting in an inhibition of cell adhesion and spreading (Tosatti et al., 2003; Schuler et al., 2006). Similarly, in our experiments U2OS cells remained rounded on mono-functional PEG coatings up to $48 \mathrm{~h}$. Such anti-fouling behaviour is mainly due to steric repulsion between the hydrated uncharged PEG chains and proteins (Jeon et al., 1991). However cell adhesion to mono-functional PEG-coatings can be achieved by introducing specific bioligands, such as a cell-interactive peptide (RGD) linked covalently to the non-fouling PEG, producing a bi-functional PEG-RGD coating. Our results show an enhanced mammalian cell adhesion to the bifunctional PEG-RGD coatings, in which already within $1.5 \mathrm{~h}$ after cell seeding, the U2OS cells showed near maximum spreading, indicating recognition of the RGDsequence by adhesion receptors in the cell membrane (Rezania and Healy, 1999). The enhanced cell attachment and spreading depends on the RGD-peptide surface density (Massia and Hubbell, 1991). The RGD-peptide surface density of around $5 \mathrm{pmol}$ RGD peptide $/ \mathrm{cm}^{2}$ applied here was well above reported densities for cell adhesion of over 0.6 pmol RGD peptide $/ \mathrm{cm}^{2}$ (Rezania et al., 1999). The former was calculated (Barth et al., 2008) based on the copolymer composition (RGD grafting density, NMR) and the adsorbed copolymer mass from in situ monitoring of the copolymer adsorption using Optical Waveguide Lightmode Spectroscopy (OWLS) (data not shown).

In the concept of the race for the surface, a full coverage of a biomaterial in vivo by a viable tissue cell layer, intact cell membranes and functional host defence mechanisms resist bacterial colonization (Gristina, 1994). Previously, in our model for the 'race for the surface', all biomaterial surfaces allowed bacterial adhesion and biofilm growth with a negative impact on the coverage of the biomaterial by mammalian cells (Subbiahdoss et al., 2010). Similarly, the presence of adhering $S$. epidermidis decreased the surface coverage of U2OS cells on $\mathrm{TiO}_{2}$ surface compared to their control, i.e. the absence of $S$. epidermidis. In contrast to the $\mathrm{TiO}_{2}$ surface, the presence of RGD-peptides at the surface significantly improved U2OS cell adhesion and spreading in the presence of S. epidermidis, eventually resulting in similar surface coverage than the control, i.e. the absence of $S$. epidermidis. Considering that cell adhesion and spreading are the signs of cellular well-being, this is highly indicative for a protective effect of cell binding to RGD in the presence of bacteria (Stupack and Cheresh, 2002). Even though complete coverage of the biomaterial surface was not obtained after $48 \mathrm{~h}$, significantly improved U2OS cell adhesion and spreading on PEG-RGD coatings could eventually lead to complete coverage of U2OS cells on biomaterial surfaces over longer periods of time. In the concept of the race for the surface, one may speculate that PEG-RGD coated implants will become more easily integrated by host tissue cells than other biomaterial surfaces and thus better protect the implant against infection.

PEG coatings have been shown to be resistant to protein adsorption, biofilm formation and cell attachment in vitro over periods of up to 4 weeks (VandeVondele et al., 2003; Fundeanu et al., 2008; Holmes et al., 2009; Fernandez et al., 2010). Depending on the exact nature of the coating, 
degradation of this biocompatible polymeric monolayer by hydrolytic/enzymatic activity has been reported. Another concern is the mechanical robustness of the PEG coatings, and if handled with surgical instruments, coatings may be easily damaged. Optichem ${ }^{\circledR}$ (Fernandez et al., 2010) and nano-particle based polymer brush coatings (Holmes et al., 2009) are mono-functional non-adhesive coatings with greater robustness than can be obtained with monolayer coatings, like the PEG-RGD coating evaluated here. The results of the present study, however, aid in directing such further development of monolayer bifunctional coatings into more robust ones, suitable for clinical use. The early protection by bi-functional coatings is believed to be clinically relevant, as it could prevent an implant from becoming colonized during the important period of actual implantation, which is critical for the longterm success of an implant (Poelstra et al., 2002; Colon et al., 2006).

\section{Conclusions}

This study demonstrates that biopassive, mono-functional PEG coatings and bioactive, bi-functional PEG-RGD coatings have potential to reduce bacterial adhesion and prevent firm adhesion of biofilms compared to common biomaterial surfaces. Moreover, in contrast to monofunctional PEG coatings, bi-functional PEG-RGD coatings allow cell adhesion and spreading. At the same time, adhesion and spreading of mammalian cells is not detrimentally affected by the presence of adhering $S$. epidermidis. Bi-functional coatings thus have a strong potential to reduce the risk of infection in applications requiring tissue integration, such as in dental and orthopaedic implants.

\section{References}

Barth KA, Coullerez G, Nilsson LM, Castelli R, Seeberger PH, Vogel V, Textor M (2008) An engineered mannoside presenting platform: Escherichia coli adhesion under static and dynamic conditions. Adv Funct Mater 18: 1459-1469.

Brunette DM, Tengvall P, Textor M, Thomsen P (2001) Titanium in Medicine: Material Science, Surface Science, Engineering, Biological Responses and Medical Applications. Springer-Verlag, Heidelberg- Berlin.

Colon G, Ward BC, Webster TJ (2006) Increased osteoblast and decreased Staphylococcus epidermidis functions on nanophase $\mathrm{ZnO}$ and $\mathrm{TiO} 2$. J Biomed Mater Res 78A: 595-604.

Dhanawade NB, Kalorey DR, Srinivasan R, Barbuddhe SB, Kurkure NV (2010) Detection of intercellular adhesion genes and biofilm production in Staphylococcus aureus isolated from bovine subclinical mastitis. Vet Res Commun 34: 81-89.

Fernandez ICS, Van der Mei HC, Metzger S, Grainger DW, Engelsman AF, Nejadnik MR, Busscher HJ (2010) In vitro and in vivo comparisons of staphylococcal biofilm formation on a cross-linked poly(ethylene glycol)-based polymer coating. Acta Biomater 6: 1119-1124.
Fitzgerald RH (1979) Microbiologic environment of the conventional operating-room. Arch Surg 114: 772-775.

Fundeanu I, Van der Mei HC, Schouten AJ, Busscher HJ (2008) Polyacrylamide brush coatings preventing microbial adhesion to silicone rubber. Coll Surf B-Biointerf 64: 297-301.

Gristina AG (1987). Biomaterial-centered infection: microbial adhesion versus tissue integration. Science 237: 1588-1595.

Gristina AG, Naylor P, Myrvik Q (1988) Infections from biomaterials and implants: a race for the surface. Med Prog Technol 14: 205-224.

Gristina AG (1994) Implant failure and the immuneincompetent fibro-Inflammatory zone. Clin Orthop Rel Res 298: 106-118.

Harris LG, Tosatti S, Wieland M, Textor M, Richards RG (2004) Staphylococcus aureus adhesion to titanium oxide surfaces coated with non-functionalized and peptidefunctionalized poly(L-lysine)-grafted-poly(ethylene glycol) copolymers. Biomaterials 25: 4135-4148.

Hermansson M (1999) The DLVO theory in microbial adhesion. Coll Surf B-Biointerf 14: 105-119.

Hersel U, Dahmen C, Kessler H (2003) RGD modified polymers: biomaterials for stimulated cell adhesion and beyond. Biomaterials 24: 4385-4415.

Holmes PF, Currie EPK, Thies JC, Van der Mei HC, Busscher HJ, Norde W (2009) Surface-modified nanoparticles as a new, versatile, and mechanically robust nonadhesive coating: Suppression of protein adsorption and bacterial adhesion. J Biomed Mater Res 91A: 824833.

Jeon SI, Lee JH, Andrade JD, Degennes PG (1991) Protein surface interactions in the presence of polyethylene oxide. 1. Simplified theory. J Coll Interf Sci 142: 149158.

Lebaron RG, Athanasiou KA (2000) Extracellular matrix cell adhesion peptides: Functional applications in orthopedic materials. Tissue Eng 6: 85-103.

Maddikeri RR, Tosatti S, Schuler M, Chessari S, Textor M, Richards RG, Harris LG (2008) Reduced medical infection related bacterial strains adhesion on bioactive RGD modified titanium surfaces: A first step toward cell selective surfaces. J Biomed Mater Res 84A: 425-435.

Massia SP, Hubbell JA (1991) An RGD spacing of $440 \mathrm{~nm}$ is sufficient for integrin alpha-V-beta-3-mediated fibroblast spreading and $140 \mathrm{~nm}$ for focal contact and stress fiber formation. J Cell Biol 114: 1089-1100.

Morra M (2000) On the molecular basis of fouling resistance. J Biomat Sci-Polymer Ed 11: 547-569.

Pasche S, De Paul SM, Vörös J, Spencer ND, Textor M (2003) Poly(L-Lysine)-graft-poly(ethylene glycol) assembled monolayers on niobium oxide surfaces: a quatitative study of the influence of polymer interfacial architecture on resistance to protein adsorption by ToFSIMS and in-situ OWLS. Langmuir 19: 9216-9225.

Poelstra KA, Barekzi NA, Rediske AM, Felts AG, Slunt JB, Grainger DW (2002) Prophylactic treatment of Grampositive and Gram-negative abdominal implant infections using locally delivered polyclonal antibodies. J Biomed Mater Res 60: 206-215. 
Rezania A, Healy KE (1999) Biomimetic peptide surfaces that regulate adhesion, spreading, cytoskeletal organization, and mineralization of the matrix deposited by osteoblast-like cells. Biotechnol Progress 15: 19-32.

Rezania A, Johnson R, Lefkow AR, Healy KE (1999) Bioactivation of metal oxide surfaces. 1. Surface characterization and cell response. Langmuir 15: 69316939.

Schuler M, Trentin D, Textor M, Tosatti SGP (2006) Biomedical interfaces: titanium surface technology for implants and cell carriers. Nanomedicine 1: 449-463.

Shi ZL, Neoh KG, Kang ET, Poh C, Wang W (2008) Bacterial adhesion and osteoblast function on titanium with surface-grafted chitosan and immobilized RGD peptide. J Biomed Mater Res 86A: 865-872.

Stupack DG, Cheresh DA (2002) Get a ligand, get a life: integrins, signaling and cell survival. J Cell Sci 115: 3729-3738.

Subbiahdoss G, Kuijer R, Grijpma DW, Van der Mei HC, Busscher HJ (2009) Microbial biofilm growth vs. tissue integration: "The race for the surface" experimentally studied. Acta Biomater 5: 1399-1404.

Subbiahdoss G, Grijpma DW, Van der Mei HC, Busscher HJ, Kuijer R (2010) Microbial biofilm growth vs. tissue integration on biomaterials with different wettabilities and a polymer - brush coating. J Biomed Mater Res A, in press. DOI: 10.1002/jbm.a.32731.

Textor M, Sittig CE, Frauchiger V, Tosatti S, Brunette DM (2001) Properties and Biological Significance of Natural Oxide Films on Titanium and Its Alloys. In: Titanium in Medicine: Material Science, Surface Science, Engineering, Biological Responses and Medical Applications (Thomsen P, ed). Springer-Verlag; Heidelberg-Berlin. pp 171-230.

Tosatti S, De Paul SM, Askendal A, VandeVondele S, Hubbell JA, Tengvall P, Textor M (2003) Peptide functionalized poly(L-lysine)-g-poly(ethylene glycol) on titanium: resistance to protein adsorption in full heparinized human blood plasma. Biomaterials 24: 4949-4958.

VandeVondele S, Voros J, Hubbell JA (2003) RGDGrafted poly-1-lysine-graft-(polyethylene glycol) copolymers block non-specific protein adsorption while promoting cell adhesion. Biotechnol Bioeng 82: 784-790.

Vasilev K, Michelmore A, Griesser HJ, Short RD (2009) Substrate influence on the initial growth phase of plasma-deposited polymer films. Chem Comm 24: 36003602 .

Verkkala K, Eklund A, Ojajarvi J, Tiittanen L, Hoborn J, Makela P (1998) The conventionally ventilated operating theatre and air contamination control during cardiac surgery - bacteriological and particulate matter control garment options for low level contamination. Eur J Cardiothorac Surg 14: 206-210.

Wagner VE, Bryers JD (2004) Poly(ethylene glycol)polyacrylate copolymers modified to control adherent monocyte-macrophage physiology: Interactions with attaching Staphylococcus epidermidis or Pseudomonas aeruginosa bacteria. J Biomed Mater Res 69A: 79-90.

\section{Discussion with Reviewers}

Reviewer I: Upon implantation of any device, the first cells that approach the device may be osteoblasts or bacteria, as were investigated in the present study, but may also be fibroblasts, endothelial cells or macrophages, etc. Do the authors expect a different experimental result dependent upon the cell type under investigation?

Authors: Yes. It is most likely that the results could change in the case of cell types such as fibroblasts, endothelial cells or macrophages. The interaction between mammalian cells and bacteria could differ depending on the type of mammalian cells and also depending on the bacterial species.

Reviewer II: Have the authors ever added the cells and bacteria to the surfaces at the same time?

Authors: No, we did not try to add the cells and bacteria to the surface at the same time. Our aim has been to focus on a peri-operative contamination model, in order to mimic the contamination occurring during the process of surgery.

Reviewer II: Do the authors have any ideas why the osteoblasts adhered better to the PEG-RGD surface compared to the bare Ti surfaces in the absence of bacteria? Authors: In general, mammalian cells bind to a biomaterial surface through adsorbed proteins and one of the main binding sites in these proteins is the RGD peptide sequence. Cells recognize the RGD binding site via integrin receptors. In this study, on the surface with PEG-RGD, the RGD binding site is directly available at the surface for the cells resulting in faster adhesion and spreading compared to bare $\mathrm{TiO} 2$ surface.

Reviewer II: Have the authors any ideas how adhered $S$. epidermidis may influence U2OS adhesion?

Authors: Initial adhesion of S. epidermidis to a biomaterial surface is the first step in biofilm formation, after which the production of extracellular polymeric substances (EPS) starts. These, substances released by S. epidermidis influences U2OS adhesion. In our previous studies, we showed that the U2OS cell adhesion and spreading are affected depending on the number of adhering $S$. epidermidis and the physico-chemical properties of the biomaterial surface (Subbiahdoss et al., 2009; Subbiahdoss et al., 2010).

Reviewer II: Have the authors looked to see how well the osteoblasts survive with the bacteria for a longer time point than 48 h? Do the bacteria keep forming a biofilm?

Authors: We have observed U2OS cells on a PMMA surface surviving till $72 \mathrm{~h}$ in the presence of S. epidermidis ATCC 35983 biofilm formation. 